\title{
A pozsonyi Erzsébet Tudományegyetem orvosi karának „rövid” története
}

\author{
Kiss László dr.
}

A pozsonyi Erzsébet Tudományegyetem orvosi karán, az ország harmadik orvosi fakultásán 1918. október 5-én kezdődött meg az oktatás. Az esemény századik évfordulója alkalom arra, hogy felelevenítsük a rövid életû pozsonyi magyar orvosképzés történetét. Meg kell ezt tennünk még akkor is, ha e lap hasábjain már két tanulmány is foglalkozott a témával [1,2]. „Rövid” emlékeztetőmben nem törekszem az általuk feltárt adatok ismétlésére - inkább arra hívom fel a figyelmet, amit ők nem mondtak, a nemzetközi internacionalizmus éveiben nem mondhattak ki a pozsonyi egyetemmel kapcsolatban [3].

$\mathrm{Az}$ 1876. évi közegészségügyi törvény elfogadását követőn fokozódik az igény az orvosi szolgáltatások iránt. $\mathrm{Az}$ igény kielégítésére két mód kínálkozik. Egyesek szerint a már meglévő budapesti és kolozsvári egyetemek orvosi karát kell erôsíteni - párhuzamos (parallel) tanszékek felállításával. Mások újabb vidéki egyetem, orvosi kar létesítését szorgalmazzák. Az 1872-től hivatalban lévő vallás- és közoktatásügyi miniszter, a felvidéki gyökerü Trefort Ágoston (1817-1888) ez utóbbi változat felé hajlik. 1881-ben előbb Pozsonyba, majd a nagy árvizet követően „halottaiból új életre feltámadt” Szegedre látogat, szakértők kíséretében [4: 174]. Kialakul az „»itt Pozsony«, »itt Szeged « jelszavak alatt harczolók arénája”. Amely arénába a Vallás- és Közoktatásügyi Minisztériumban az egyetemi ügyek előadójaként dolgozó - s mellesleg az Orvosi Hetilap fószerkesztője - Markusovszky Lajos nem kíván belépni, ám egy tárca erejéig elmondja nézetét. Valószínúnek tartja, hogy főnöke „egyetemi háztűznézése" folytatódni fog - Kassa és Pécs is sorra kerülhet -, a szakértők adatokat gyüjtenek, véleményeket formálnak majd. Ő mégis úgy véli, hogy „az új egyetem székhelyének megválasztásánál is csak magának a tervezett intézetnek fogalma és hivatása lehet vezérelvünk és útmutatónk" [4: 175]. Az említett arénahangulat csillapítására írja: „Az új egyetem elhelyezésének kérdése nem vitatható szenvedéllyel, hanem komolysággal; kulturális kérdés az első sorban és csak másod sorban politikai; pártkérdés pedig épen nem...” [4: 175].

Nos, e kulturális kérdés megoldását is szolgálta az a "szakértői enquête", melyet a képviselőház közoktatási bizottsága hívott össze 1883. május elejére. A budapesti és a kolozsvári egyetemek szakértői vitatták meg - a budapesti egyetem túltömöttsége, a jogi akadémiák reformja mellett - a harmadik egyetem felállításának kérdé- seit. A budapesti orvosi kart Korányi Frigyes és Fodor József képviselte. Ez utóbbi felszólalásának kivonatát Markusovszky lapja közölte. Miután okos érvekkel utasítja vissza a „túltömöttségre” hivatkozók ötletét a parallel tanszékek felállítására, Fodor a pesti orvosi kar nevében kimondja: „... én egy harmadik egyetem felállítását szükségesnek és sürgetőnek, s abban orvosi kar berendezését nélkülözhetetlennek tartom" [5: 542].

Nos, Pesten, távol az érintett helyszínektől könnyebb volt az „arénahangulat”, a szenvedélyesség mellőzése. A helyszínen, esetünkben Pozsonyban viszont a szenvedélyesség elvárt követelmény! Idézünk egy, az említett konferenciát követően, a vallás- és közoktatásügyi miniszter „kiváló figyelmébe” ajánlott füzetből:

„Vajon Pozsony, mely az állami testnek oly jelentős része, nem várhatja-e el méltán a nemzettől, hogy rásüsse nemzeti egységének bélyegét, hogy itt a határszélen öntudatos politikát üzve, egy nagyszabású főiskola keletkezzék, mely a Lajtán túlról magyar földre lépőnek azonnal hirdesse, hogy a föld, melyen megállott, magyar?” [6: Ajánlás].

Az idézett sorok szerzője az 1864-ben megnyílt pozsonyi magyar királyi Országos Kórház belgyógyász főorvosa, Pávai Vajna Gábor (1850-1913) volt. A debreceni születésű Pávai Vajna csak alig másfél évvel korábban költözött Pozsonyba. Ennek ellenére, lelkes pozsonyi lokálpatriótaként, ő lett a harmadik egyetem Pozsonyban való létesítésének egyik legszenvedélyesebb szószólója. Mivel ő volt a belgyógyászat függelékeként múködő „elmekórtani osztály” foorvosa és „a boncolások vezetésével megbízott" is, jó áttekintése volt az akkoriban 182 ágyas intézmény múködéséről. A fentebb már idézett munkájában - többek közt - így érvel Pozsony mellett: „A pozsonyi m. kir. országos kórház ... valódi mintaintézetnek tekinthető ... van célszerú boncterme ... van egy általam szövettani és más vizsgálatokra berendezett dolgozó szobája, a szükséges górcsövekkel és más, a betegek tüzetes vizsgálatára megkívántató eszközökkel és villanygépekkel stb. ..." [6:27]. A napjainkban a tüdővész elleni küzdelem egyik úttörőjeként számon tartandó Pávai Vajna [7] még két alkalommal, 1887-ben, illetve 1907ben tett közzé egy-egy röpiratot a leendő pozsonyi egyetem érdekében. Az előbbiben, „a vallás- és közokt. ügyi tárca költségvetéseinek tárgyalása alkalmából a képviselőház tagjainak nagybecsü figyelmébe" ajánlva, így érvel: 
„... lesz elég diák, csak rendelje el a miniszter, hogy csak az nyerhet nyilvános, hivatalos orvosi állást, ki hazai egyetemen végzett vagy hogy orvosként csak az múködhetik, ki nostrifikáltatta bécsi (nyugati) diplomáját" [8: 13]. Az 1907-es röpiratának címzettje már maga a miniszter, gróf Apponyi Albert (1846-1933), aki 1906-tól áll a Vallás- és Közoktatásügyi Minisztérium élén. Röpiratában újabb érveket sorol fel Pozsony mellett:

A korridorrendszerben épített kórház területén 1901től külön pavilonja van az elmebetegeknek és külön pavilonja a fertőző betegeknek, „továbbá külön kórbonctani intézet, a megfelelő berendezéssel és kórszövettani meg kórvegytani vizsgálatokra szükséges dolgozó helyiségekkel, amelyekhez ravatalozásra egy stílszerú kápolna is van építve... már építés alatt a 120 ágyra tervezett sebészeti pavillon... 1898 óta van külön Röntgen-laboratórium, mely annak idején első volt Magyarországon..." [9: 11].

Pávai Vajna és a többi „szenvedélyes” pozsonyi kitartása csak több mint negyed évszázad után vezetett sikerre. Az 1912. július 11-én elfogadott XXXVI. tc. utasította a vallás- és közoktatásügyi minisztert - gróf Zichy Jánost (1868-1944) - a pozsonyi és a debreceni egyetem megszervezésére. A törvénycikkely szépséghibája: nem mond ki időpontokat - ennek megfelelően a megvalósítás konkrét lépései csak nagyon tétován követték egymást [2: 645]. Pozsonyban 1913-ban megnyílik a jogi kar, majd 1914. április 2-án az orvosi fakultás is. Pontosítva: a pozsonyi Országos Kórház belgyógyászati és - a közben átadott új - sebészeti osztályát, valamint a pozsonyi Bábaképzőt klinikává nyilvánították, foorvosaikat pedig egyetemi tanárrá léptették elő. A „tudományegyetemi nyilvános rendes tanár" címet az 1913-ban elhunyt Pávai Vajna örökébe lépett Herzog Ferenc (1879-1952), az 1912-ben elhunyt kiváló sebész, Lumniczer-tanítvány, Schmid Hugó utóda, Bakay Lajos (1880-1959) és a Tauffer-tanítvány, szülész-nőgyógyász Velits Dezső (1860-1921) nyerte el.

Létrejött tehát egy orvosi kar három professzorral, de tanársegédek, sőt medikusok nélkül. E szokatlan kezdetre így emlékezik a sebészet professzora: „... a sebészeti klinika ezen elhelyezését - értsd: az országos kórbázban; K. L. - teljesen ideiglenesnek tekintettük, amint az a kinevezési okiratomból is kitûnik, amely arra kötelez, hogy a pozsonyi egyetem megnyitásáig a pozsonyi állami kórház sebészeti osztályán a főorvosi teendőket is ellássam. Biztosítást nyertünk azonban az irányban, hogy az új klinikák építése hamarosan megkezdődik" [10].

Nos, e „biztosítást” az 1914 nyarán Szarajevóban eldördült lövések tették hiteltelenné. A kitört háború - a később „nagy”, illetve „első világháború” névre rászolgált világesemény - nemcsak az új klinikák építési terveit tette megvalósulatlanná, hanem a közben kinevezett tanársegédeket is a frontra vezényelte. A 34 éves sebészprofesszornak nemcsak „klinikáján”, hanem a szintén orvos nélkül maradt XIX. számú helyőrségi kórház sebészetén is helyt kellett állnia. 1915 júliusától pedig a ma- gyar rokkantügy egyik vidéki fellegvárává váló Országos Hadigondozó Hivatal Pozsonyi Intézetének vezetését is ellátta [11].

Hasonló nehézségekkel kellett megbirkózniuk Bakay tanártársainak is. Növekszik a bábaképzőbe „elhanyagoltan beszállított szülési esetek száma”, hiszen nemcsak orvos-, de bábahiány is van: „... a pozsonyi bábaképezdében a tót anyanyelven oktatott bábáknak és éppen a legintelligensebbjeinek jókora száma értékesíti nálunk szerzett tudását a dollárok hazájában, ahol a magyar bábaoklevélnek igen nagy becsülete van" [12]. Herzognak is, aki a budapesti II. Belgyógyászati Klinika adjunktusi állását hagyta ott Pozsonyért, meg kellett elégednie az „ideiglenes” klinikával. Ennek ellenére, a vidéki és háborús körülmények közt is, figyelmet keltő dolgozatokat publikál. Még a pesti munkahely feltüntetésével, de már „pozsonyi ny. r. tanár”-ként jelentet meg 1914 novemberében egy háromrészes dolgozatot [13]. A pozsonyi kazuisztikákat feldolgozó írása viszont arról tanúskodik, hogy Herzog sosem tekintette klinikának saját osztályát - az 1918 tavaszán megjelent közleménye „a pozsonyi állami kórház belosztályáról" származik [14]. S bár egy 1920-ban megjelenő dolgozatának lábjegyzete - „A pozsonyi Erzsébet-egyetem belklinikájának megnyitásakor 1918. szeptember 7-én tartott előadás" [15] - belklinikát hirdet, ez csak „kegyes csalás”: a klinika a régi osztály falai közt nyílt meg.

E három, 1914-ben kinevezett professzor csak 1918 áprilisában kap újabb kollégákat. A kórbonctan élére Entz Béla (1877-1959) kerül. A gyermekgyógyászati tanszék professzora és egyben az 1857-tól múködő Ferenc József Gyermekkórház igazgatója Heim Pál (18751929) lesz. Reuter Camillo (1874-1954) az elmegyógyászat, ifj. Imre József (1884-1945) a szemészet, Fenyvessy Béla (1873-1954) a közegészségtan, Veress Ferenc (1877-1957) a bőrgyógyászat, Pekár Mihály (1871-1942) az élettan professzora lett.

Megkülönböztetett figyelmet érdemel a gyógyszertan professzora és intézete. A professzori címet a 36 éves Mansfeld Géza (1882-1950) kapja, aki már korábbi müködési helyén, Marburgban (a mai szlovén Mariborban) együtt dolgozott Szent-Györgyi Alberttel (1893-1986). A majd 1937-ben Nobel-díjat kapott Szent-Györgyi Mansfeld első tanársegéde lett. Kevésbé köztudott, hogy Mansfeld keze alatt dolgozott egy másik leendő Nobeldíjas is, a prágai születésü Carl Ferdinand Cori (18961984). Cori 1947-ben, amerikai állampolgárként kapott Nobel-díjat (feleségével együtt) a glikogén katalitikus átalakulásának felfedezéséért. A teljesség kedvéért: Mansfeld később kétszer is szerepelt a Nobel-díjra jelöltek között [16]. Mansfeld és kis csapata a pozsonyi intézetben a szívizom funkcióját tanulmányozta, és erról három publikációjuk jelent meg az élettani kutatások egyik legrangosabb tudományos fórumában, a Pflügers Archiv für die gesamte Physiologie des Menschen und der Tiere hasábjain 1920-ban [17]. 
Az 1918-as év a professzori kar kiegészítésén kívül meghozta minden egyetem nélkülözhetetlen „kellékét”, az egyetemi hallgatókat is. 1918. október 5-én megkezdődik az oktatás - egyelőre csak a III., IV. és V. évfolyam számára. Az első két évfolyam alaptantárgyainak oktatására még nem voltak meg az anyagi feltételek [18: 173$174]$.

Az 1918 őszén bekövetkezett köztörténeti események ismertetését mellőzve, az orvosi kar históriája röviden így vázolható: az oktatás csak rövid ideig folyt zavartalanul. 1918. december 30-án a Csehszlovák Légió és az olasz R. Barreca ezredes katonái megszállták Pozsony fontosabb középületeit. Alig egy hónappal később Pozsony, Bratislava néven, az újonnan alakult utódállam, Csehszlovákia szlovenszkói (szlovákiai) részének székhelye lett. Ide költözött a Szlovenszkó igazgatásával megbízott teljhatalmú minisztérium, melynek élére egyébként egy Prágában végzett orvosdoktor, Vavro Šrobár (1867-1950), a köztársasági elnök, Masaryk bizalmát élvező rózsahegyi (Ružomberok) gyakorló orvos került. Šrobárt, pánszlávizmusa miatt, közvetlenül az érettségije előtt kizárták valamennyi magyarországi iskolából, 1906ban ugyanilyen okból a szegedi börtön rabja volt. 1918 . november 4-én ő lett az új állam, Csehszlovákia első egészségügyi minisztere, majd december 10-étől a már említett teljhatalmú miniszter [19].

Šrobár 1919. február 4-én a cseh legionáriusok sorfala között, diadalkapu alatt vonult be a Bratislavának elkeresztelt Pozsonyba. A bevonulási terv szerint a város vezetőinek és a magyar intézmények képviselőinek kellett volna köszönteniük Šrobár kormányát. Az Erzsébet Egyetem tanácsa úgy döntött, nem vesz részt ezen a megalázó aktuson. Távolmaradásukat az egyetem rektora, Polner Ödön (1865-1961) jogászprofesszor így indokolta:

„Az egyetemi tanács tudatában van annak, hogy a nevezett kormánnyal szemben nemcsak a lojalitás, hanem az udvariasság követelményeinek is eleget kell tennie. De azt hisszük, hogy a követelmények egyikével sem jövünk ellentétbe, ha a magyar hazafiságunkat nem tagadjuk meg. Azokban az ünnepségekben pedig, melyek Magyaroszág nagymértékű megcsonkítása feletti örömnek a kifejezését jelentik, résztvenni, legszentebb hazafiúi érzelmeinkkel éles ellentétben van. Ily körülmények közt a jelzett ünnepségeken résztvennünk részünkról erkölcsi lehetetlenség” [20].

A hatalom válasza nem késett: Samuel Zoch kormánybiztos január 28-án bezáratja az egyetemet, a tanári kart rendőri felügyelet alá helyezi. A város, melynek lakossága az 1910-es népszámláláskor 42\%-ban németnek, 41\%ban magyarnak vallotta magát, rádöbben, hogy Pozsony megszállása - az antant ígérete ellenére - nem „ideiglenes" lesz [21: 59]. Sztrájkhullám kezdődik, amelynek vezetői 11 pontos követelést fogalmaznak meg. Az 1. helyen szereplő „A népek önrendelkezési jogának, valamint a lelkiismereti szabadság elvének elismerése" mellett a 2. pont „A pozsonyi tudományegyetem újból való megnyitását” követeli [22]. 1919. február 12-re általános (figyelmeztető) sztájkot hirdetnek, melynek kicsúcsosodása a délután 3-ra tervezett népgyúlés lett volna. Ami ekkor történt, arról a pozsonyi Hiradó - az egykori Nyugatmagyarországi Hiradó; a magyar jelző használatát Zoch betiltotta - másnapi száma ezt írta: „... a cseh katonaság pár perc alatt szinte ostrom alá vette a várost és gépfegyvertüzzel, feltűzött bajonettel verte szét a népgyuulést, de minden kis csoportosulást, ártatlan járókelőket is”. „Sohasem felejtem el azt a látványt, melyet klinikám a február 12-iki vérengzéskor nyújtott - emlékezik évek múltán a pozsonyi sebészprofesszor. - Délután két órakor, amikor a sürgôs telefonhívásra besiettem, az egész földszinti folyosót, valamint az ambulantiai helységeket mindenkorú és nemú súlyos sebesültekkel telve találtam, akiket két tanártársam, Pekár Mihály és Entz Béla segítettek hordányon beszállítani. A folyosó végén pedig egymás mellett leterítve feküdtek a kiszenvedett áldozatok" [10: 23-24].

Az egyetemet két hét múlva a szlovák gyökerü, de 1918-ig magyarul publikáló Jehlicska Ferenc (18791939), a budapesti teológia volt professzora, mint az egyetem csehszlovák kormánybiztosa, újra ünnepélyesen megnyitotta. Az egyetem jövője körüli bizonytalanság azonban egyre fokozódik. Ez készteti az egyetemet arra, hogy 1919. május 27-én Polner rektor vezetésével küldöttség menjen Prágába az egyetemi tanárból lett köztársasági elnökhöz, Tomáš Garrigue Masarykhoz (18501937). Masaryk kitérő választ ad, nyugtatgat: a pozsonyi magyar egyetem nem fog hirtelen, minden átmenet nélkül megszűnni [23]. Bakay, aki a küldöttség tagja volt, így emlékezik: „Biztosítást nyertünk arra nézve, hogy intézeteink és klinikáink tovább múködhetnek és a tanítás nyelvében sem történik legalább tíz évig változás, mert mint (Masaryk) mondá: »Nem azért jöttünk, hogy a régi kultúrát megsemmisítsük, amelyet ma még pótolni nem tudunk «" [10:24]. A reménykedve hazaérkezett küldöttség tagjai megdöbbenve fogadják a hírt: 1919. június 26-án a csehszlovák nemzetgyúlés megszavazta az Erzsébet Egyetem megszüntetéséről szóló törvényt. Masaryk e törvény alapján adja ki a 365-ös számú elnöki dekrétumát, amely a magyar egyetem helyébe csehszlovák egyetem felállítását rendeli el Pozsonyban [23].

Az orvosi (és bölcsészeti) kar vezetősége már szeptemberben értesítést kap, hogy minden vagyonukat adják át a csehszlovák egyetem képviselőinek. Annak ellenére, hogy mind a város, mind az újonnan létesített közigazgatási egységek, a zsupák (megyék) vezetői az orvoskar megtartása mellett foglalnak állást, a teljhatalmát élvező Šrobár doktor szíve nem lágyult meg magyar orvoskollégái iránt. Szeptember másik felében megtörténik a klinikák, intézetek átadása az új egyetem rektorának, a Prágából érkezett müncheni születésű Kristián Hynek (1879-1960) frissiben kinevezett belgyógyászprofesszornak a jelenlétében. E becsvágyó, Prágában érvényesülni nem tudó cseh orvosnak nem kis szerepe volt Šrobár döntésében. Elhitette a még tétovázó szlovák 
teljhatalmú miniszterrel, hogy várhatóan bezárják a prágai Károly Egyetem német részlegét is, tantestületének nagynémet vonzalmai miatt [24: 39]. 1919 decemberében az új egyetem - Masaryk kívánsága szerint - a tanárként Sárospatakon is megfordult Jan Amos Komenskýnek, azaz Comeniusnak (1592-1670), a morva husziták kelyhes gyülekezete püspökének a nevét veszi fel. A 70\%ban katolikus szlovákok többsége számára érthetelen volt ez a névadás. „Olyan személyról nevezni el egyetemet, aki a szlovákoknak nem sokat jelent, értük nem sokat tett, csak azt célozta, hogy a szlovákokat megsértsék és megalázzák...” [24: 42].

1920 elején a budapesti egyetem orvosi kara átiratot intéz a külföldi egyetemek orvoskaraihoz:

„Mint egyetemi tanárok gyászoljuk Pozsonyt. Fiatal egyetemének kiépítését megakasztotta a háború. Múltja nincs, de vele elveszett a jövő, melynek biztosítékát láttuk kitünő tanítványainkból álló tanári karában... Egyetlen fegyverünk az igazság maradt. Ez győzött kezünkben 1000 év viszontagságai felett és győzni fog a jövőben is. Benne bízva tiltakozunk az igaz emberek és tudósok előtt az igazságtalanságnak s a kultúra elragadásának ténye ellen" [25].

\section{Irodalom}

[1] Duka Zólyomi N. Erzsébet University in Pozsony and its medical faculty. [A pozsonyi Erzsébet Tudományegyetem és orvosi kara.] Orv Hetil. 1978; 119: 1853-1857. [Hungarian]

[2] Kapronczay K. The issue of a newer medical faculty at the end of 19th century. [Újabb orvosi kar kérdése a századfordulón.] Orv Hetil. 1987; 128: 641-645. [Hungarian]

[3] Kiss L. Once upon a time there was a medical faculty - a "brief history" of the Medical Faculty of the Erzsébet University in Pressburg (1914-1919). [Volt egyszer egy orvosi kar - a pozsonyi Erzsébet Egyetem Orvosi Karának „,rövid története” (19141919).] Comm de Hist Artis Med. 2010, 210-213: 205-214. [Hungarian]

[4] Markusovszky L. In the matter of the third Hungarian University. [A harmadik magyar tudományegyetem ügyében.] Orv Hetil. 1882; 26: 171-176. [Hungarian]

[5] Fodor J. About the third Hungarian University. [A harmadik magyar egyetemről.] Orv. Hetil. 1883; 23: 535-542. [Hungarian]

[6] Pávai Vajna G. Pozsony and the third Hungarian University [Pozsony és a harmadik egyetem.] Pozsony, 1884. [Hungarian]

[7] Kiss L. The pioneer of the fight against tuberculosis in Pressburg, the forgotten disciple of Frigyes Korányi: Gábor Pávai Vajna (1850-1913). [A tüdővész elleni küzdelem pozsonyi úttörője, Korányi Frigyes elfeledett tanítványa: Pávai Vajna Gábor (18501913).] Orv Hetil. 2013; 154: 792-795. [Hungarian]
[8] Pávai Vajna G. Where to found the third university? [Hol állítsuk fel a harmadik egyetemet?] Pozsony, 1887. [Hungarian]

[9] Pávai Vajna G. The advantages of the medical faculty of the third university in Pozsony. [A pozsonyi harmadik egyetem orvosi fakultásának előnyei.] Pozsony, 1907. [Hungarian]

[10] Bakay L. Eleven years of the surgical clinic of Erzsébet University. [A m. kir. Erzsébet Tudományegyetem sebészeti klinikájának tizenegy esztendeje.] Orvosképzés 1925; 15: 3. [Hungarian]

[11] Magyar LA. The first Hungarian factory of prostheses. In: Kapronczay K. (ed.) War and medicine. $[\mathrm{Az}$ első magyar múvégtaggyár. In: Kapronczay K. (szerk.) Háború és orvoslás.] Magyar Orvostörténelmi Társaság, Budapest, 2015; pp. 182189. [Hungarian]

[12] Velits D. About the influence of the war on the fate of bearing women. [A háború befolyásáról a szülőnók sorsára.] Pozsony, 1916. [Hungarian]

[13] Herzog F. About the myasthenic weekness based on the myoelectric and histological examination of the muscle. [A myastheniás elfáradásról az izom múködési áramának vizsgálata és a szövettani lelet alapján.] Orv Hetil. 1914; 58: 815-817, 832834., 845-847. [Hungarian]

[14] Herzog F. About the prognosis of the chronic peritonitis. [Az idősült hashártyalob kórjelzéséről.] Orv Hetil. 1918; 62: 137139. [Hungarian]

[15] Herzog F. Health and disease. [Egészség és betegség.] Orvosképzés 1920; 10: 83-88. [Hungarian]

[16] Szállási Á. Secrets of Nobel-prize. [A Nobel-díj „titkaiból”.] Orv. Hetil. 2004; 145: 303-304. [Hungarian]

[17] Szolcsányi J. Albert Szent-Györgyi looking back at the start of his research profession and his master, Géza Mansfeld in 1943. [Szent-Györgyi Albert visszatekintése 1943-ban kutatói pályakezdésére és mesterére, Mansfeld Gézára.] Orv Hetil. 2007; 148: 2007-2011. [Hungarian]

[18] Bokesová-Uherová M. History of public health in Slovakia. [Dejiny zdravotníctva na Slovensku.] Osveta, Martin, 1989. [Slovak]

[19] Gogola M. Vavro Srobár, the first professor of social medicine in Slovakia. [Vavro Šrobár, prvý profesor sociálneho lekárstva na Slovensku.] Revue medicíny v praxi. 2017; 15: 55-56. [Slovak]

[20] Szôke J. Quizzing the past. The ceremonial procession of the Slovak government in Pozsony. [Múltfaggató. A szlovák kormány ünnepélyes bevonulása Pozsonyba 1919-ben.] Új Szó 1993. febr. 11. [Hungarian]

[21] Tiszai L. Capital without Slovak past. [Fôváros szlovák múlt nélkül.] Nagy Magyarország 2009; 1: 59-63. [Hungarian]

[22] Filep TG. The historian moves on. [A történész továbblapoz.] Új Szó, 2005. febr. 18. [Hungarian]

[23] Szőke J. Quizzing the past. The closing of the Erzsébet University in Pozsony. [Múltfaggató. A pozsonyi Erzsébet Egyetem bezárása.] Új Szó 1993. márc. 26. [Hungarian]

[24] Mesko GZ. Silent conspiracy. [A csendes összeesküvés.] Európa Könyvkiadó, Budapest, 2006. [Hungarian]

[25] Miscellanies. [Vegyes hírek.] Orv Hetil. 1920; 64: 93. [Hungarian]

(Kiss László dr., SK-93 008 Csilizradvány 284., Szlovákia e-mail: kiss.agi@panelnet.sk) 